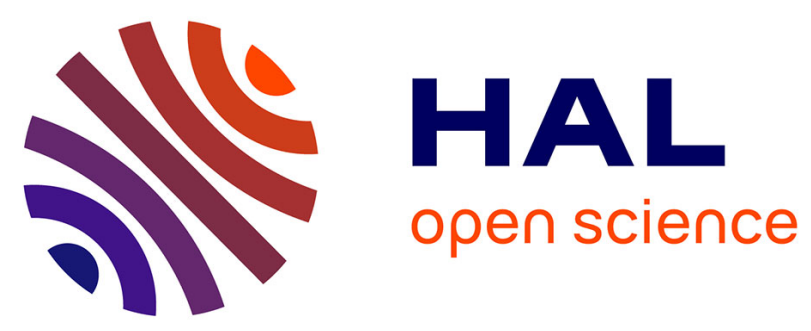

\title{
The Green IT Certification Ruled by the Infotercio Financial Model
}

Nilo Costa Serpa, Ivanir Costa, Diego Rodrigues, Rodrigo Franco Gonçalves

\section{To cite this version:}

Nilo Costa Serpa, Ivanir Costa, Diego Rodrigues, Rodrigo Franco Gonçalves. The Green IT Certification Ruled by the Infotercio Financial Model. IFIP International Conference on Advances in Production Management Systems (APMS), Sep 2014, Ajaccio, France. pp.22-29, 10.1007/978-3-66244736-9_3 . hal-01387841

\section{HAL Id: hal-01387841 \\ https://hal.inria.fr/hal-01387841}

Submitted on 26 Oct 2016

HAL is a multi-disciplinary open access archive for the deposit and dissemination of scientific research documents, whether they are published or not. The documents may come from teaching and research institutions in France or abroad, or from public or private research centers.
L'archive ouverte pluridisciplinaire HAL, est destinée au dépôt et à la diffusion de documents scientifiques de niveau recherche, publiés ou non, émanant des établissements d'enseignement et de recherche français ou étrangers, des laboratoires publics ou privés. 


\title{
The Green IT Certification Ruled by the Infotercio Financial Model
}

\author{
Nilo Serpa ${ }^{1}$, Ivanir Costa $^{2}$, Diego Rodrigues ${ }^{1}$ and Rodrigo Franco Gonçalves ${ }^{1}$ \\ ${ }^{1}$ UNIP - Graduate Program in Production Engineering, Brazil \\ ${ }^{2}$ UNINOVE - Graduate Program in Production Engineering, Brazil \\ niloserpa@gmail.com, icosta11@live.com, diego@unip.br, rofranco@osite.com.br \\ http: //www .unip.br
}

\begin{abstract}
Present article gives continuity to the elaboration of the infotercio financial model proposed as an alternative to implementing environmental management systems in governmental institutions based on the emission reduction of printed reports, source codes and forms originated from IT activities. It discusses procedures of green IT certification for managers and governmental institutions derived from ISO 14000 family and People CMM, combining both in a new set of requirements. Also it summarizes the reasons for such a certification system, noting that waste paper is now a major global problem, not only in terms of direct environmental impacts but from the point of view of the unreasonable and unnecessary use of paper in governmental business processes, generating high costs, mismanagements and time losses, at the same time causing reduction in the available physical space in corporate environments and increase in fuel consumption for transport.
\end{abstract}

Key words: green IT, people CMM, green certification, waste paper, infotercio, sustainability, cleaner production

\section{Introduction}

From the strong conflicts between public and private interests concerning environmental management during the seventies and the eighties, the growing general awareness about the damage caused to Earth and human health along the evolution of production processes and the huge social inequalities existing around the planet have allowed organizations to manage their ecosystemic impacts with higher responsibility. The concept of sustainable development, created in 1987 by the United Nations, came up with the aim of promoting agreement between contender parties.

In a former work ${ }^{1}$, the authors pointed out that paper constitutes a large portion of IT waste in governmental institutions as spurious or unnecessary printed reports, source codes and forms, although the subject is still not treated with the fitting attention but included in a generic approach of sustainable development

\footnotetext{
${ }^{1}$ Entitled "Green IT and Waste Paper in Governmental Institutions: The Proposal of the Infotercio Financial Model", also submitted and accepted in APMS 2014.
} 
([8], [13], [14]). As they note, green IT is now much focused on environmental certifications and metrics on general waste emissions ([5], [12]) and virtualization as a mean for reducing significantly electricity rates [1]. Actions of Green IT supporting businesses have been described with little written specifically about IT office paper use and disposal. To cease to be waste, paper from IT services has to be considered under a set of emissions reduction procedures connected to a certain green certification for organizations and managers.

This article takes as starting point the infotercio financial model, explained earlier, proposing a green certification system associated with the model and characterized by maturity levels to both institution and manager. The Standard to be proposed contains only those requirements that can be objectively audited for certification/registration and/or self-declaration refering to waste paper management. Additional guidance on other matters relating to environmental management must be searched in ISO 14000 family. The authors emphasize that it is essential to read the previous article so that we can have a full comprehension of the subject.

\section{Background}

As we know, more than half of all office waste is constituted by paper. Worldwide paper is one of the bigest sources of trash. The numbers are astronomical; just to give an idea, according to the Department of Environment and Conservation (DEC), Sydney, until 2005 Australians consumed around 3.5 million tonnes of paper each year, in which only $11 \%$ of total office paper was recycled [2]. At 2007, Brazil spent $42 \mathrm{~kg} /$ inhab.year compared to larger consumers like United States, for example, with a per capita consumption of $288 \mathrm{~kg}$ /inhab.year and France with a rate of $144 \mathrm{~kg} /$ inhab.year. Founded on these rates, it is expected that consumption shall increase very fast in next decades whether nothing is done ASAP.

The infotercio ( $\$$ INFO), as previously defined, is a unit of green financial credit to promote IT governance in compliance with the green principle that the greater the reduction in the emission of printed paper the higher the available credit to modernize IT areas (see Fig. 1). The value in dollars of that unit depends on the current governmental policies. As no cash is involved, just green credits computed by external IT audits, the model helps to reduce the risk of misappropriation of public funds. It was created specifically for IT governmental management also with the objective of environmental education in public institutions about the use of paper and its disposal after utilization, linking resources availability to corporate performance regarding the reduction of waste paper. Unlike carbon credits, infotercios may not be transferred or sold to other institutions. To achieve significant adhesion to green IT under the infotercio financial model it is necessary to go through the adoption of a certification ritual that is not limited only to the institution but capable of being extended to the IT manager himself. 


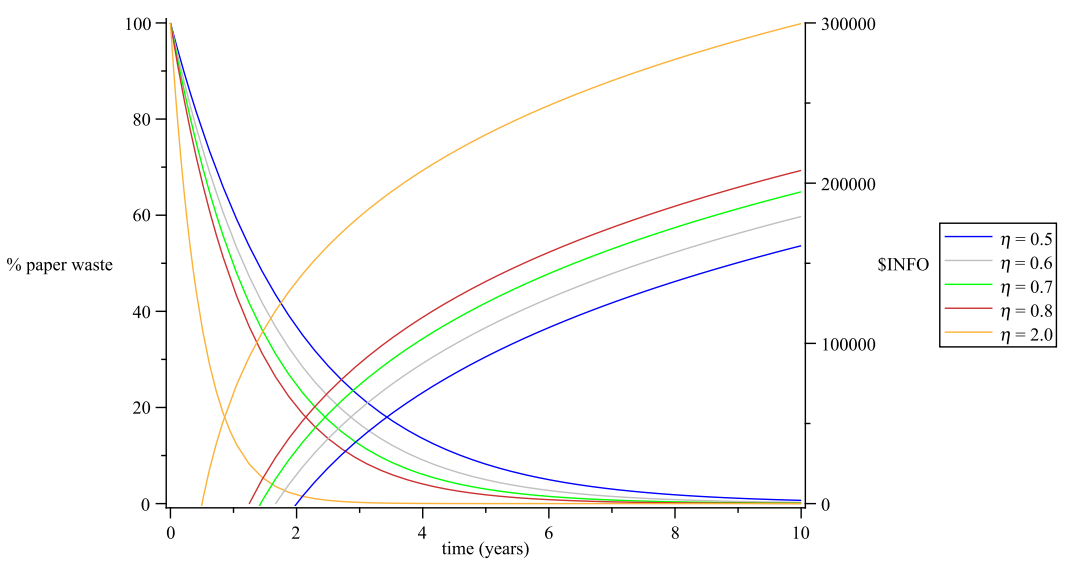

Fig. 1. The mathematical evolution of the paper waste reduction and the corresponding credits in infotercios for distinct values of the coefficient of waste decay $(\eta)$.

Brazilian public institutions are far from achieve consolidated internal processes to reduce waste generation. In particular, with respect to the waste paper there is a complete slouch on the amount of unnecessary or misdefined printed reports, which invariably end up in the trash or in the drawers of managers without even serve as scratch paper. Cardboard boxes accumulated in the corridors of the IT coordinations serve as trash cans for printed papers coming from the bad exercise of environmental sustainability and from the absence of document management frameworks. Although concerned to the issue of resources for IT, the infotercio financial model emerges as a solution to the problem of waste paper in governmental institutions, promoting improvements, environmental education and professional qualification.

\section{The ISO environmental state-of-art and the new NBR-INFO 2014}

The ISO 14000 family [4], at first glance regarding only private environmental management, provides an organization with standards and management tools to voluntarily control environmental aspects related to its existence and daily interactions with human beings, urban or rural landscape and others ${ }^{2}$. This set of tools and standards, if well implemented, provides economy associated with environmental benefits. Accordingly ISO, among these benefits we have reduction of waste generation and optimization of waste management, using processes such

\footnotetext{
${ }^{2}$ According to NBR-ISO 14004 (1997), the environment is considered the surroundings in which a certain organization conducts its business, including air, water, land, natural resources, flora, fauna and humans, as well as their interrelations.
} 
as recycling to treat solid waste. The only standard series ISO 14000 certifiable with respect to environmental management is ISO 14001:2004.

Although most small and medium enterprises (SME) have little knowledge or interest in environmental issues [3], the number of organizations certified by ISO 14001 has grown worldwide and should remain so in face of the increasing demands for environmental sustainability. In European Union, Marimon et al. point 1,096 IT organizations certified in 2008 compared to only 139 in 2000 [7]. The number does not seem very meaningful in a computerized world partly due to the high costs associated with the implementation of ISO 14000 [15], in particular ISO 14001, a fact that can indeed become a barrier for many institutions. However, for governmental institutions like Ministries not all features of ISO 14000 are necessary, since these organizations do not carry out processes of recycling or incineration but can perform reductions of paper emissions implementing ECM (Enterprise Content Management) and business intelligence dashboards, so that those high costs can no longer be a barrier if institutions start from a basic environmental management systems (EMS). Also, while ISO 14001 specifies only general requirements for operating EMSs with no resolves on how or to what extent to do this [10], organizations can develop their own solutions to be in compliance with the standard's demands. This is what infotercio financial model must provide: a green IT certification based only in paper economy. This certification shall be linked to a special Brazilian norm, named NBR-INFO 2014, prescribing scopes, gradual aims and patterns with sudgestions about tools and processes, so that institutions can rationalize the use of renewable and nonrenewable resources.

\section{The Green People Capability Maturity Model}

The IT manager career has been gaining more and more expression from the beginning of the 21st century at the same time that main focus has shifted to services. It is a sophisticated profile, in a constant process of adaptation and acquisition of diverse knowledge about various subjects. Although not formally recognized, in practice it has, by analogy, the same importance of the old systems analyst during the 80s. As an administrative career on IT processes and technologies, it can be valued through specializations, postgraduate courses and certifications, though none of them replace the accumulated experience. The infotercio financial model provides a green certification based on People Capability Maturity Model (P-CMM) as a way to characterize the manager's expertise, offering an important item of professional ascension within a market increasingly competitive in quality.

The P-CMM is a tool that employs a maturity framework of best practices for managing and developing human resources based on the successful Capability Maturity Model for software (SW-CMM), guiding institutions in the improvement of their processes related to the pursuit of the human capital excellence by five maturity levels. P-CMM helps institutions to characterize the maturity of their people practices, establishing a program of continuous amelioration and 
integrating people development with process improvement. Version 1 of P-CMM was released in 1995. Version 2 has been designed to correct Version 1, since experience has pointed that many organizations start formal development of workgroups while working toward Maturity Level 3, on the contrary of placing team-building activities at Maturity Level 4 as prescribed in Version 1. So, Version 2 starts process-driven workgroup development at Maturity Level 3.

The infotercio financial model presumes a green P-CMM solely concerning to management proficiency on environmental issues. Based on the adapted model from Rodrigues [11], we consider a proposal for continuing professional education, inserting the concept of maturity levels targeted to green IT. Rodrigues identifies four levels of maturity in their adapted model: (i) Level 0 - Definition of parameters, (ii) Level 1 - Planning, (iii) Level 2 - Quantification of Performance, (iv) Level 3 - Optimization of Performance, as shown in Fig. 2, considering indicators KMB (Knowledge Monitoring Bias) and KMA (Knwoledge Monitoring Accuracy) [11]. Each of the four maturity levels points to a different stage of organizational capability for managing and developing human resources in the sense of to attain sustainable processes of waste paper control. Maturity levels provide layers for continuous improvement of workforce proficiency in environmental sustainability.

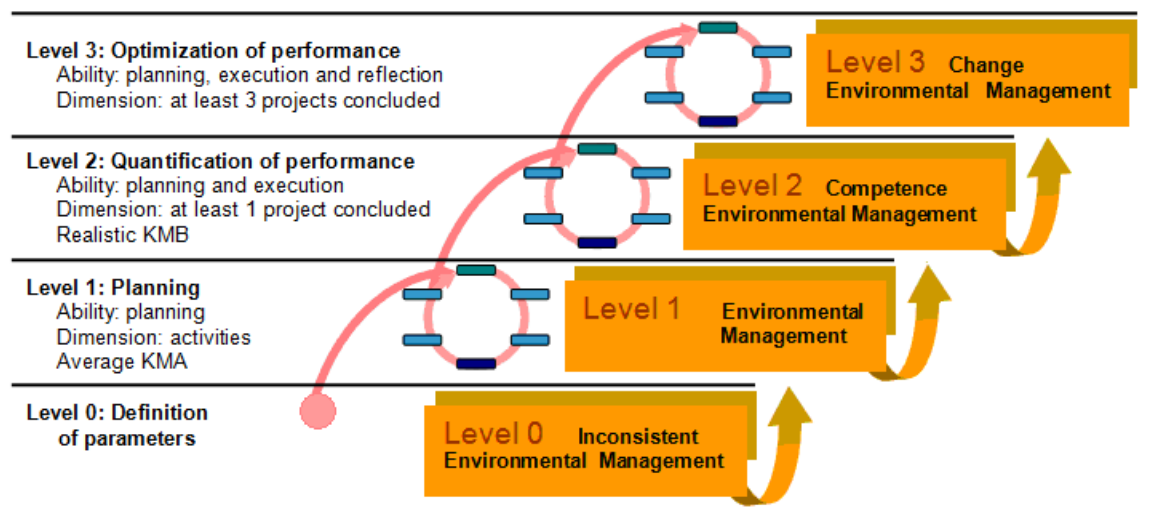

Fig. 2. The four maturity levels of the green P-CMM.

On one hand, in the first article the authors established the so-called green IT card to be granted to the IT manager interested in establishing corporate policies to reduce the emission of printed paper. On the oder hand, levels of personal maturity are assessed throughout the career of the manager according to its proficiency to lead the trend of exponential emission reduction of printed paper. Thus, the green IT card shall also have four levels (Fig. 3), each of them offering some additional privileges: i) Level 0 - no stars; ii) Level 1 - one star; c) Level 


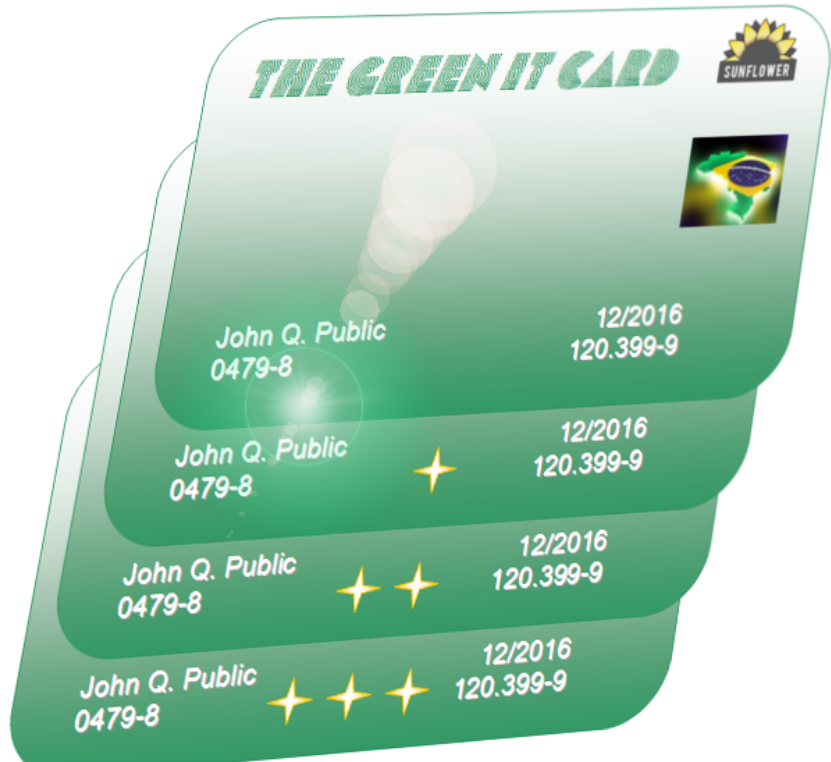

Fig. 3. The four green cards.

2 - two stars; d) level 3 - three stars. This card will be activated whenever the manager take public charges and disabled when targeted for natural exoneration.

\subsection{The perspectives of the NBR-INFO 2014}

The NBR INFO-2014 is a standard still under development, now submited to consideration of many stakeholders, researchers and academics. It applies to those environmental aspects of waste paper that can be controlled by the workforce of a governmental institution like consumption and waste disposal. Since there is already a full standard on environmental management for organizations, the ISO family 14000 , it would be redundant to prescribe a new standard with basically the same requirements. Thus, the NBR-INFO 2014 shall specify detailed requirements on environmental management only with regard to the use and disposal of paper generated by the activities of IT and the means to process optimization that can contribute to reduce the emission of reports, source codes and forms according to the infotercio financial model and its remuneration policy of continuous improvement of IT in order to achieve sustainable containments on paper consumption. This standard applies to all types and sizes of governmental institutions, adapting to different geographic, cultural and social conditions. Indeed, system's success shall depend on the degree of commitment of all corporate areas, starting with senior management, since there is compli- 
ance between corporate governance and IT governance [9]. Thus, the NBR-INFO 2014 adhering institutions shall set their own environmental goals while balancing environmental protection and pollution prevention with social needs.

The reader must pay attention to the fact that this specification shall describe the requirements for certification/registration and/or self-declaration of the EMS of a governmental institution, with guidelines not intending to cover issues with market and competitive implications. It should be noted that this standard does not establish absolute requirements for environmental performance beyond the expressed commitment within the corporate internal policy, in compliance with infotercio financial model's prescription of continual improvement.

\section{Comments}

As an integral part of the overall management system of the organization, the EMS provides order and consistency to addressing ecological concerns through ongoing evaluation of practices, procedures and processes in coordinated action with efforts of other areas such as quality, operations, finance and health [6]. According to proposed approaches in the former article, green IT card allows IT managers to lead the implementation of the EMS sustainability measures, being a symbol of responsability and proficiency since it may only be granted to managers with proven experience and expertise in environmental issues, and ongoing interest in the acquisition and preservation of their certifications.

Unfortunately, in Brazil it is not enough the existence of standards like ISO 14000 to be fulfilled to achieve production improvements. There are serious problems in education and ethical issues that still require additional inspection agencies. Also, institutional maturity remains a barrier to be overcome. The authors have sudgested the Federation General Comptroller (FGC) as the institution responsible for the audits on the results achieved, with their internal automated processes having drastically reduced emissions of reports, keeping working through frameworks for information management and real-time monitoring of their databases related to institutional programs of sustainability. Interacting with this organization, each governmental IT manager detainer of a green IT card, with which he can monitor the amount of available infotercios, can also compute professional credits every successful action within the proposed corporate planning, registered and monitored by the FGC, thus composing his portfolio of accomplishments for further analysis of personal maturity level.

\section{Conclusion}

This article presented the natural extension of the infotercio financial model, that is, the green IT certification process for institutions and managers that conduct internal policies to reducing emissions of printed paper from IT services. The proposal is inserted into the scope of cleaner production and sustainability as an option to control current state of paper consumption in governmental institutions still not much concerned to ecological principles in Brazil. Restraining 
the use of paper in governmental business processes, it shall be possible to reduce costs, mismanagements and time losses, increasing the available physical space in corporate environments and economizing fuel for transport. Our expectation is that the complete model can be presented and tested soon at the ministerial level, demonstrating feasibility and raising discussions that promote improvement of the standard NBR-INFO 2014, now in development.

\section{References}

1. Cristóvão, A., Costa, I., Neto, A.P.A., Cao Ji Can: A Case Study on the Benefits that Virtualization Provides the IT and its Positive Impact on the Environment. In: APMS 2012 International Conference Advances in Production Management Systems, The Pennsylvania State University, Pennsylvania (2012)

2. DEC - Department of Environment and Conservation: Reducing Paper Waste at Work, http://www.livingthing.net.au/rc/guides/05638 Paperwaste.pdf

3. Halila, F., Tell, J.: Creating Synergies Between SMEs and Universities for ISO 14001 Certification. Journal of Cleaner Production 48, 85-92 (2013)

4. ISO - International Organization for Standardization: Environmental Management: The ISO 14000 Family of International Standards, http://www.iso.ch

5. Jenkin, T.A., Webster, J., McShane, L.: An Agenda for 'Green' Information Technology and Systems Research. Information and Organization 21, 17-40 (2011)

6. Jorgensen, T. H.; Remmen, A.; Mellado, M. D.: Integrated Management Systems: Three Different Levels of Integration. Journal of Cleaner Production 14, 713-722 (2006)

7. Marimon, F., Llach, J., Bernardo, M.: Comparative Analysis of Diffusion of the ISO 14001 Standard by Sector of Activity. Journal of Cleaner Production 19, 1734-1744 (2011)

8. Merrild, H., Damgaard, A., Christensen, T.H.: Life Cycle Assessment of Waste Paper Management: The Importance of Technology Data and System Boundaries in Assessing Recycling and Incineration. Resources, Conservation and Recycling $52,1391-1398$ (2008)

9. MH - Ministry of Health: Technical Guidelines for Preparation of the Program of Health Education and Social Mobilization (HESMP); Implementation, Expansion or Improvement of Systems of Treatment and Final Disposal of Solid Waste for the Control of Diseases. ASCOM/FUNASA, Brasilia, Brazil (2004)

10. Oliveira, O., Serra, J., Salgado, M.: Does ISO 14001 Work in Brazil? Journal of Cleaner Production 18, 1797-1806 (2010)

11. Rodrigues, D.: Um Modelo de Assistente Reflexivo para Suporte à Educação Continuada em Ambiente Organizacional. Master Thesis, Catholic University of Brasilia, Brasilia, Brazil (2010)

12. Siegler, K., Gaughan, B.: A Practical Approach to Green IT, http://www.itmanagement.com/land/green-it-webinar/?tfso $=2058$

13. Villanueva, A., Eder, P.: End-of-Waste Criteria for Waste Paper: Technical Proposals. Publications Office of the European Union, Luxembourg (2011)

14. Villanueva, A., Wenzel, H.: Paperwaste-Recycling, Incineration or Landfilling? A Review of Existing Life Cycle Assessments. Waste Management 27, 29-46 (2007)

15. Wiengarten, F., Pagell, M., Fynes, B.: ISO 14000 Certification and Investments in Environmental Supply Chain Management Practices: Identifying Differences in Motivation and Adoption Levels Between Western European and North American Companies. Journal of Cleaner Production 56, 18-28 (2013) 